\title{
PERAN PENDIDIKAN TERHADAP EKSISTENSI KEHIDUPAN MASYARAKAT ADAT KAMPUNG NAGA, TASIKMALAYA, JAWA BARAT
}

\author{
Oleh: \\ Itok Dwi Kurniawan \\ Universitas Sebelas Maret Surakarta \\ e-mail: itokdwikurniawan@staff.uns.ac.id \\ Hassan Suryono \\ Universitas Sebelas Maret Surakarta
}

\begin{abstract}
One of the most important aspects of life is education, thinking and human behavior along with the education has been taken. Education is one of the most important efforts for a nation in maintaining its existence. The purpose of this research is study the role of education to the existence the custom society of Kampung Naga, Tasikmalaya, West Java. This research is a qualitative research with descriptive qualitative method. The data used in the form of qualitative data. Data collection techniques used are observation and literature review. The data analysis techniques using interactive models. The results of research is shown that the important of education role to existence for custom society life of Kampung Naga, Tasikmalaya, West Java. It is shown that the role of education provides more usefulness, but does not change their behavior. There is not only formal education that already exists but also balanced with environmental education in the form of education from family. This education is done so that they can teach the pattern of hereditary behavior that has existed from an early age so that their existence will still survive. They is custom society is not easy along the formal and custom so there are some problems about education. The role of Tasikmalaya Regency Government to encourage indigenous Kampung Naga community for formal education needs to be improved
\end{abstract}

Keywords: Education, Custom Society 


\section{PENDAHULUAN}

Adat istiadat merupakan warisan paling tak ternilai harganya. Begitu pula bagi masyarakat adat Kampung Naga. Masyarakat adat Kampung Naga merupakan masyarakat yang tinggal di lembah di daerah Tasikmalaya. Masyarakat Kampung Naga masih sangat memegang tradisi/adat istiadat nenek moyang mereka dengan baik, hal itu terlihat dari struktur kehidupan disana. Banyak hal yang menarik yang dapat diamati dari kehidupan masyarakat Adat Kampung Naga seperti aspek uparacara-upacara/ ritual-ritual, tata kehidupan, serta proses pendidikan. Hal itu menjadi salah satu hal yang menarik banyak orang bahkan wisatawan asing untuk berkunjung dan mengetahui seluk beluk dan kehidupan masyarakat Adat Kampung Naga secara langsung.

Seperti yang kita ketahui pendidikan merupakan aspek terpenting dalam kehidupan, pemikiran dan tingkah laku manusia berjalan seiring dengan berjalannya pendidikan yang di tempuh. Pendidikan merupakan salah satu upaya terpenting bagi suatu bangsa dalam mempertahankan eksistensinya.

Pendidikan sebagai usaha
membina dan mewariskan
kebudayaan, mengemban satu
kewajiban yang luas dan menentukan
prestasi suatu bangsa, bahkan tingkat

sosio-budaya. Oleh karena itu, pendidikan bukan hanya sebagai usaha dan aktifitas spekulatif semata, pendidikan harus didasarkan pada asas-asas filosofis dan ilmiah demi tercapainya suatu tujuan yakni mempertahankan dan meningkatkan perkembangan sosio-budaya suatu masyarakat.

Pelaksanaan pendidikan dalam masyarakat adat Kampung Naga memiliki filosofi pendidikan tidak membatasi warga masyarakatnya untuk mengenyam pendidikan. Di zaman modern seperti sekarang ini selain menerapkan pendidikan adat, untuk tetap mempertahankan eksistensi dan keberlangsungan hidup warga masyarakat Adat Kampung Naga juga menerapkan pendidikan formal.

Sehingga dalam hal ini pendidikan di Kampung Naga terbagi menjadi dua persepsi yakni pendidikan formal dan non-formal. Hal ini sesuai yang diamanatkan dalam Undang-Undang Nomor 20 Tahun 2003 tentang Sistem Pendidikan Nasional bahwa pendidikan adalah usaha sadar dan terencana untuk mewujudkan suasana belajar dan proses pembelajaran agar peserta didik secara aktif mengembangkan potensi dirinya untuk memiliki kekuatan spiritual keagamaan, pengendalian diri, kepribadian, kecerdasan, akhlak mulia serta keterampilan yang diperlukan dirinya dan masyarakat. 
Hal tersebut dibuktikan dengan tingkat pendidikan masyarakat adat Kampung Naga yakni mayoritas SD namun masih banyak juga yang menempuh pendidikan SMP, SMA bahkan ada yang mengenyam pendidikan sarjana. Sedangkan pendidikan non formal sebagai usaha untuk membina dan mewariskan kebudayaan, mengemban satu kewajiban yang luas dan menentukan prestasi suatu bangsa. Pendidikan non formal di masyarakat Adat Kampung Naga lebih ditekankan pada budi pekerti dan tata perilaku.

Pendidikan yang terdapat di dalam masyarakat adat Kampung Naga tentunya memiliki peranan dalam kehidupan masyarakat meskipun tidak terlalu berpengaruh bagi kehidupan sosial-budayanya yang dapat dibuktikan dengan keadaan masyarakat Adat Kampung Naga masih memegang erat tradisi/adat istiadat yang syarat dengan nilainilai tradisional Sunda dan Islam, namun tidak memungkiri bahwa pendidikan memiliki peranan bagi perekonomian, cara pandang masyarakat, dan lain sebagainya.

\section{METODE PENELITIAN}

Penelitian ini merupakan penelitian kualitatif dengan menggunakan metode kualitatif deskriptif. Bogdan dan Taylor (Moleong, 2011: 4) mendefinisikan metode kualitatif sebagai prosedur penelitian yang menghasilkan data deskriptif berupa kata-kata tertulis atau lisan dari orang-orang dan perilaku yang dapat diamati.

Subyek dalam penelitian ini adalah masyarakat adat di Kampung Naga, Desa Neglasari, Kecamatan Salawu, Kabupaten Tasikmalaya, Jawa Barat. Teknik pengumpulan data yang digunakan observasi dan studi pustaka. Data yang dikumpulkan berupa data kualitatif. Teknik analisis data kualitatif menggunakan model interaktif yang dikembangkan oleh Miller dan Huberman (2007: 36) yang terdiri dari empat langkah yaitu: 1) pengumpulan data; 2) reduksi data; 3) penyajian data; dan 4) penarikan kesimpulan atau verifikasi.

\section{HASIL PENELITIAN DAN PEMBAHASAN}

A. Sekilas Pendidikan di Kampung Naga, Tasikmalaya, Jawa Barat

Kampung

Naga

merupakan kampung adat yang masih menjunjung tinggi dan berpegang teguh pada nilai adat dan istiadat nenek moyangnya, kampung ini terletak di Desa Neglasari, kecamatan Salawu, Kabupaten Tasikmalaya. Penduduk Kampung Naga sangat patuh terhadap pemerintah, terbukti dengan filosofi nya yang menarik yaitu “ Panyaur gancang temonan, parentah gancang lakonan, pamundut gancang caosan, Pamarentah lain lawaneun tapi 
kawulaaneun, pamarentah sanes tempat menta tapi pamarentah tempat kumawula". Artinya kurang lebih begini, "apabila dipanggil segera penuhi, apabila diperintah cepat dilakukan dan apabila ada keinginan cepat kabulkan, pemerintah bukan untuk dilawan tapi untuk diayomi dan mengayomi”.

Kampung Naga adalah sebuah perkampungan asli yang menjunjung tinggi adat istiadat sunda, karena itu harus tetap dilestarikan sebagai bukti kepada anak cucu bahwa bangunan, dan adat orang sunda adalah seperti ini. Namun yang disayangkan adalah pendidikan penduduk Kampung Naga mayoritas SD, padahal Pemerintah bisa membantu mensosialisasikan pendidikan dengan program kesetaraan misalnya Kejar paket B dan C. Selain menjunjung tinggi adat istiadat, mereka juga sangat kental sekali akan adanya agama yang mengiringi kehidupannya. Mayoritas atau dapat dikatakan di sana semua masyarakatnya adalah beragama Islam. Setiap adat yang dijalankan, kebanyakan terdapat keberpengaruhan dari agama Islam itu sendiri.

Tingkat Pendidikan

masyarakat Kampung Naga mayoritas hanya mencapai jenjang pendidikan sekolah dasar, tapi adapula yang melanjutkan pendidikan ke jenjang yang lebih tinggi itupun hanya minoritas. Masyarakat mengaku kurang sosialisasi tentang pendidikan, hal ini terbukti dengan adanya seorang anak yang sejak SMP sudah memiliki prestasi di sekolah, namun disayangkan tidak dapat melanjutkan pendidikannya dan hanya menjadi pengrajin di rumah. Untuk pendidikan nonformal di Kampung Naga ini setiap hari senin-jumat jam 14.00 selalu diadakan pengajian untuk anak-anak.

B. Sarana dan Prasarana Pendidikan di Kampung Naga, Tasikmalaya, Jawa Barat

Dalam hal sarana dan prasarana pendidikan yang ada dalam masyarakat adat Kampung Naga dapat dilihat dari tiga sumber utama yang diberikan, yaitu sarana dan prasarana dari keluarga, sarana dan prasarana dari adat, maupun sarana dan prasarana yang diberikan dari pemerintah setempat. Pertama, sarana dan prasarana yang diberikan oleh keluarga atau orang tua. Secara umum, setiap oang tua yang menginginkan anaknya sekolah pasti harus membiayai mereka. Begitu pula dengan masyarakat 
adat Kampung Naga, setiap orang tua dengan kemampuan masing-masing memberikan sarana dan prasarana berupa dukungan materil, dan formil. Kemudian materi yang dimaksud berupa uang saku layaknya anak sekolah pada umumnya, biaya sekolah di sekolah masing-masing. Hingga dukungan motivasi yang diberikan untuk hidup lebih pintar. Tentu menjadi suatu hal yang harus ditekankan perihal motivasi belajar dari orang tua, mengingat pendidikan disana yang dapat dikatakan sangat rendah, bahkan orang ua yang tidak bersekolah. Harus menjadi poin perhatian semangat belajar mereka sebagai anak adat yang hidup disekeliling moderniasasi dan banyaknya tourist yang berkunjung.

Kedua, sarana dan prasarana yang diberikan baik secara langsung ataupun tidak langsung oleh masyarakat adat Kampung Naga terkhusus melalaui pimpinan adat. Para anak-anak diberikan fasilitas berupa rumah belajar bersamasering kita ketahui sebagai pendopo- serta masjid desa. Ditempat ini mereka belajar berupa pengetahuan umum dilingkungan formal maupun pengetahuan tentang keadatan. Tidak hanya itu, sesuai dengan informasi yang didapat, adapula sebuah bimbingan belajar yang didirikan oleh salah satu waga yang juga sekaligus salah satu guru pengajar di SD dari masyarakat itu sendiri. Tentu ini menjadi poin tambahan bagi anak-anak disana, karena dengan adanya bmbingan belajar akan menjadikan pembelajaran tambahan dalam persaingan dan perebutan pengetahuan di sekolah formal.

Ketiga, sarana dan prasarana yang diberikan oleh Pemerintah setempat. Ada beberapa sarana dan prasarana yang secara langsung diberikan oleh pemerintah melalui beasiswa tidak mampu sering kita ketahui BLT (Bantuan Langsung Tunai) maupun beasiswa berupa operasional (BOS). Tentu dengan adanya program pemerintah tersebut memberikan keringan terhadap beban keluarga, terlebih pada posisi hidup yang berkecukupan. Sedangkan dalam hal sarana dan prasarana yang diberikan secara tidak langsung salah satunya berupa minyak tanah. Artinya minyak tanah yang dapat digunakan sebagai penerangan ini dapat membantu dan memberikan fasilitas berupa penerangan, menginat di Kampung Naga tidak terdapat listrik karena menolak untuk dialiri listrik. Namun, hal-hal yang secara khusus dalam 
pendidikan di Kampung Naga, sebagaimana informasi yang didapat pemerintah belum memiliki upaya yang khusus dan inten dalam memajukan kampung adat tersebut. Hal ini dibuktikan belum adanya perhatian secara khusus dalam hal pendidikan berupa bantuan atau saraa prasarana. Walaupun demikian, tidak menyurutkan anak-anak dalam belajar dengan kondisi yang tidak seperti masyarakat biasa, terbukti prestasi mereka pada bangku sekolah formal memiliki ratarata yang sama dengan penduduk luar kampung adat tersebut.

\section{Kendala Pendidikan di} Kampung Naga, Tasikmalaya, Jawa Barat

Persoalan mengapa kebanyakan masyarakat adat tidak mendapat pendidikan formal terjadi karena dua alasan. Pertama, kendala biaya. Seringkali mereka tidak mempunyai cukup uang untuk membayar biaya sekolah di sekolah formal. Seperti yang dialami oleh masyarakat adat di Kampung Naga ini, dikarenakan pendapatannya yang minim sebagian dari mereka tidak mampu melanjutkan pendidikan ke jenjang yang lebih tinggi. Untuk saat ini sebenarnya sudah banyak program pembiayaan pendidikan dari pemeritah seperti Biaya Operasional Sekolah (BOS), Bantuan Siswa Miskin (BSM), dan masih banyak program lain sehingga sedikit memudahkan beban mereka untuk dapat melanjutkan pendidikan. Tetapi, kenyataannya berdasarkan hasil observasi yang telah dilakukan program tersebut di atas belum dirasakan oleh sebagian masyarakat adat di Kampung Naga. Hal ini memang tak mengherankan terjadi dikarenakan berdasarkan beberapa kasus yang ada, dana bantuan dari pemerintah tersebut tak tepat sasaran pada seseorang yang seharusnya mendapatkan.

Kendala yang kedua disini adalah rendahnya minat dan motivasi anak untuk bersekolah. Winkel mengatakan bahwa minat adalah kecenderungan yang agak menetap untuk merasa tertarik pada bidangbidang tertentu dan merasa senang berkecimpung dalam bidang itu (1983: 38), sedangkan menurut Witherington (1985: 38) minat adalah kesadaran seseorang terhadap suatu objek, seseorang, suatu soal atau situasi tertentu yang mengandung sangkut paut dengan dirinya atau dipandang sebagai sesuatu yang sadar. Dapat disimpulkan bahwa 
pengertian minat adalah aspek psikis yang dimiliki seseorang yang menimbulkan rasa suka atau tertarik terhadap sesuatu dan mampu mempengaruhi tindakan orang tersebut.

Menurut Johanes yang dikutip oleh Bimo Walgito (1999: 35), menyatakan bahwa "Minat dapat digolongkan menjadi dua, yaitu minat intrinsik dan ektrinsik. Minat intrinsik adalah minat yang timbulnya dari dalam individu sendiri tanpa pengaruh dari luar. Minat ekstrinsik adalah minat yang timbul karena pengaruh dari luar". Berdasarkan pendapat ini maka minat intrinsik dapat timbul karena pengaruh sikap. Persepsi, prestasi belajar, bakat, jenis kelamin dan termasuk juga harapan bekerja. Sedangkan minat ekstrinsik dapat timbul karena pengaruh latar belakang status sosial ekonomi orang tua, minat orang tua, informasi, lingkungan dan sebagainya.

Berdasarkan hasil

observasi yang telah dilakukan, bahwasannya apabila ditinjau dari minat, maka yang menjadikan anak yang tinggal di Kampung Naga tidak bisa melanjutkan pendidikan ke jenjang yang lebih tinggi adalah dikarenakan minat ekstrinsik sehingga menjadikan minat intrinsik menggebu. Sebagian besar dari mereka tak dapat melanjutkan ke sekolah sebab lingkungan keluarganya tak mendukung dalam hal perekonomian. Minat ekstrinsik yang satu ini menjadikan seorang anak mau tidak mau harus prihatin dengan kondisi keluarganya apalagi disana didukung dengan kondisi anak yang masih dalam kendali penuh orangtua. Selain itu, orangtua disana walaupun tetap memberikan dorongan penuh agar anaknya tetap menempuh pendidikan, para orangtua disana tetap mengajarkan beberapa keterampilan untuk mengantisipasi anaknya tak putus asa ketika pendidikan formalnya tidak bisa dilanjutkan. Dengan begini, menjadikan pengertian berbeda bagi anak sehingga dapat diartikan bahwa pendidikan tak dilanjutkanpun tak apa selama mereka menguasai keterampilan turuntemurun yang berasal dari orangtuanya. Maka, dari keadaan lapangan itu disimpulkan bahwa minat intrinsik itu tidak ada melainkan minat intrinsik tersebut terbentuk atau terjadi karena dorongan dari minat ekstrinsik. Dapat dikatakan yakni minat yang benar-benar menjadikan seseorang melakukan tindakan sesuatu yang diinginkan disini tidak mungkin penuh karena minat intrinsik yang nyata dari 
dirinya akan tetapi minat
akstrinsik dari luar tetap
mempengaruhi seberapa
kecilnya itu. Jadi, dengan begitu
yang terjadi adalah minat
ekstrinsik anak yang semakin
besar karena adanya jaminan
kehidupan yang lebih baik
apabila tidak bisa melanjutkan
pendidikan maka akan
meningkatkan minat intrinsiknya
untuk melakukan tindakan yang
sesuai dengan keadaannya yakni
tidak melanjutkan sekolah.

Menurut Herzberg dalam

Koontz (1990: 123), ada dua jenis faktor yang mendorong seseorang untuk berusaha mencapai kepuasan dan menjauhkan diri dari ketidakpuasan.

1. Faktor Higiene (faktor ekstrinsik): Memotivasi seseorang untuk keluar dari ketidakpuasan, termasuk didalamnya adalah hubungan antar manusia, imbalan, kondisi lingkungan, dan sebagainya.

2. Faktor Motivator (faktor intrinsik): Memotivasi seseorang untuk berusaha mencapai kepuasan, yang termasuk didalamnya adalah achievement, pengakuan, kemajuan tingkat kehidupan, dan sebagainya. Apabila ditinjau dari teori motivasi Herzberg di atas maka yang menimbulkan rendahnya motivasi masyarakat Kampung Naga adalah faktor motivator yang mana disini orangtua memotivasi para anaknya sedari dini telah diajarkan untuk mencapai kepuasan yakni dengan memajukan tingkat kehidupan melalui keterampilan baik membuat anyaman maupun bertani yang memang sudah temurun sejak dahulu yang mana harus dijaga. Dari sini walaupun maksud dari orangtua sendiri tidak untuk menurunkan motivasi anaknya dalam pendidikan akan tetapi disana ada satu anak bernama Tia motivasinya menurun karena minatnya akan menganyam jauh lebih tinggi didorong dengan kondisi ekonomi yang tak memenuhi menyebabkan ia tak melanjutkan sekolahnya. Dengan adanya hal tersebut daripada minatnya tidak timbul apapun untuk menutupi kesedihannya karena tak bisa melanjutkan sekolah maka dibangunlah faktor motivator lebih tinggi lagi kepada anak tersebut untuk meningkatkan keterampilannya dalam hal menganyam. Hal ini sejalan dengan hasil penelitian dari Damanik (2010) dan Putra (2012) yang melakukan penelitian terkait dengan faktor motivasi dan minat siswa dalam 


$\begin{array}{lrr}\begin{array}{l}\text { mengikuti } \\ \text { pembelajaran } \\ \text { akademik } \\ \text { akademik. }\end{array} & \text { malam } & \begin{array}{r}\text { kegiatan } \\ \text { bidang }\end{array} \\ \text { non- }\end{array}$

\section{Peran Pendidikan Bagi} Eksistensi Kehidupan Masyarakat Adat Kampung Naga, Tasikmalaya, Jawa Barat

Sejak dahulu masyarakat di Kampung Naga memang dianjurkan untuk mengutamakan pendidikan bagi setiap dirinya. Hal tersebut terlukis dalam filosofi yang dijunjung oleh masyarakat adat Kampung Naga sendiri. Walaupun kebanyakan mayoritas dari mereka dahulu tak sampai menyelesaikan jenjang SD, tapi mereka tetap menggali potensi dari dirinya di lain pendidikan. Dengan memanfaatkan dan mengolah apa yang ada di sekitarnya serta menggali pengetahuan lebih terhadap apa yang ingin diketahuinya memberi dampak tersendiri bagi eksistensi kehidupan masyarakat adat Kampung Naga.

Seiring perkembangan, kini masyarakat Kampung Naga mampu menempatkan generasinya ke jenjang pendidikan yang lebih tinggi lagi yakni jenjang SMA. Akan tetapi, memang tak semuanya mampu menempuh sampai jenjang SMA terlebih sampai Perguruan
Tinggi. Banyak kendala yang ada yang membuat seseorang dari Kampung Naga tersebut tidak bisa melanjutkan pendidikannya. Walau begitu, pendidikan yang dapat dikatakan masih dalam kategori rendah, tetap dapat membawa dampak terhadap berbagai hal bagi eksistensi masyarakat adat Kampung Naga yakni dalam pola pikir, sosial-budaya, bahkan ekonomi mereka.

\section{Pola Pikir}

Pola adalah bentuk atau patron atau model atau juga cara. Dengan demikian, pola pikir itu sebenarnya adalah bentuk pikir atau cara kita berpikir yang disebut “ Mindset " Kata Mindset terdiri atas dua kata yakni "mind" dan "set". Mind merupakan sumber pikiran dan memori atau pusat kesadaran yang menghasilkan pikiran, perasaan, ide, dan menyimpan pengetahuan dan memori tentang segala macan hal-hal yang pernah dilakukan sendiri maupun kejadian apa saja yang dibaca, dilihat, dan dilakoni diri sendiri maupun orang lain. Sedangkan set adalah kepercayaan-kepercayaan yang mempengaruhi sikap seseorang; atau suatu cara berpikir yang menentukan 
prilaku dan pandangan, sikap dan masa depan seseorang.

Dengan demikian mindset atau pola pikir itu adalah kepercayaan (belief) atau sekumpulan kepercayaan (set of beliefs) atau cara berpikir yg mempengaruhi prilaku (behavior) dan sikap (attitude) seseorang yg akhirnya menentukan level keberhasilan (nasib) hidupnya. Setiap orang atau manusia secara individu pada dasarnya memiliki ide, pendapat, rencana, cita-cita. Unsur-unsur tersebut diolah oleh otak / akal / pikiran dan selalu dipengaruhi atau ditentukan oleh attitude atau sikap perilakunya.

Jadi, dapat disimpulkan pola pikir adalah cara berpikir seseorang dlm mewujudkan ide/ pendapat/ rencana/ citacitanya yang dalam pelaksanaannya dipengaruhi pula oleh perasaan/ pandangannya ataupun sikap prilakunya (attitude) tentang sesuatu itu secara umum. Dgn kata lain pada suatu saat sikap seseorang itu dipengaruhi oleh perasaan atau emosinya.

Kampung Naga
merupakan salah satu
kampung adat yang masih
sangat menjunjung tinggi Dan
masih tetap berpegang nilai

adat dan istiadat nenek moyangnya Pendidikan merupakan aspek terpenting dalam kehidupan, pemikiran dan tingkah laku manusia berjalan seiring dengan berjalannya pendidikan yang dia tempuh. Arti dari pendidikan itu sendiri merupakan perubahan tingkah laku yang dapat diamati. Pendidikan dan kondisi sosial berjalan beriringan dan yang satu memberikan dampak terhadap satunya, sedangkan di Kampung Naga kedua aspek tersebut berjalan sendiri-sendiri dalam arti tetap berhubungan tetapi pendidikan tidak memberikan dampah yang signifikan terhadap kondisi sosial, buktinya masyarakat Kampung Naga masih memegang erat tradisi/adat istiadat yang syarat dengan niali-nilai tradisional.

Pewarisan budaya berarti pewarisan pola pikir hakikatbya adalah pikiran itu seniri sementara pikiran itu tidak dapat terlihat yang dapat dilihat adalah ketika pemikiran tersebut diaplikasikan dalam perbuatan. Dalam Kampung Naga memiliki filsafat yaitu: 
a. Saur elingkeun zaman kaulaan salaras jeung agama, pamarentah, undang-undang jeung norma-norma

b. Nginduk kana pajamanan ngiring kana kurikulum

Ketika kita bertutur kata yang baik, ketika mengahdapi zaman yang terus berkembang ikuti perubahan itu. Namun yang penting adalah ketika kita mengikuti perubahan zaman pilihlah perubahan yang sesuai dengan syariat-syariat agama islam, sesuai dengan pemerintah, undang-undang dan selaras dengan normanorma yang berlaku.

Masyarakat Kampung Naga sadar akan pentingnya pendidikan oleh karena itu mereka mengusahakan agar anak-anaknya dapat mendapatkan pendidikan. Pendidikan yang ditempuh oleh sebagian besar masyrakat Kampung Naga tidak mempengaruhi pola pemikirannya. Pola pemikiran masyarakat Kampung Naga yang mendapatkan pendidikan formal tetap lokal yaitu tetap menjunjung tinggi nilai-nilai adat istiadat setempat. Masyarakat di Kampung Naga mempunyai falsafah bahwa pemikiran global tetapi tetap lokal, maksudnya dengan mendapatkan pendidikan maka pemikiran masyarakat akan berkembang lebih maju namun kemajuan pemikirannya tersebut tidak mengubah pola pemikiran mereka yang tetap mempertahankan nilai-nilai yang ada dalam adat tersebut.

\section{Perekonomian}

Salah satu tujuan yang harus dicapai oleh pendidikan adalah mengembangkan keterampilan hidup. Pendidikan merupakan suatu daktor kebutuhan hidup untuk setiap manusia sehingga upaya mencerdaskan kehidupan bangsa karena melalui pendidikan upaya peningkatan kesejahteraan masyarakat dapat tercapai. Pendidikan mempunyai pengaruh terhadap pertumbuhan ekonomi melalui berkembangnya kesempatan untuk meningkatkan kesehatan, pengetahuan, dan ketarmpilan, keahlian, serta wawasan mereka agar mampu lebih bekerja secara produktif, baik secara perorangan maupun kelompok.

Sebagian besar masyarakat di Kampung Naga mendapat atau telah menempuh pendidikan. 
Pendidikan yang diperoleh masyarakat Kampung Naga berdampak pada berbagai aspek kehidupan dalam masyakarat Kampung Naga. Salah satunya adalah dibidang ekonomi, pendidikan yang diperoleh masyarakat mempengaruhi perekonomian di masyarakat Kampung Naga. Dengan memperoleh pendidikan maka terbentuk kompetensi dan kreatifitas. Hampir mayoritas masyarakat di Kampung Naga adalah petani sehingga dengan adanya pendidikan maka masyarakat menjadi tau bagaimana cara untuk menanam, komponen apa saja yang dibutuhkan agar tanaman tumbuh subur, dan cara merawat tanaman. Oleh karena itu pendidikan disini mempermudah masyarakat dalam pelaksanaan kegiatan perekonomian di kampung naga.

Selain itu dengan pendidikan maka akan memunculkan kreatifitas. Di Kampung Naga banyak penduduk yang membuat barang barang dari bambu, seperti tas, sandal, topi, bermacam suvenir dan lain lain. Pendidikan yang diperoleh penduduk berupa cara atau teknik dalam pembuatan barang barang tersebut. Barang-barang tersebut kemudian dijual kepada wisatawan yang berkunjung di kampungnya. Dengan begitu maka penduduk akan memperoleh penghasilan tambahan.

\section{KESIMPULAN}

Berdasarkan hasil penelitian yang telah diuraikan dalam pembahasan dapat disimpulkan bahwa:

1. Pendidikan di Kampung Naga masih dapat dilakukan dalam artian masih berjalan walaupun terdapat beberapa kendala salah satunya faktor ekonomi yang rendah merupakan masalah yang belum dapat terselesaikan, di sisi lain telah adanya bantuan namun bantuan tersebut sebagian masyarakat Kampung Naga tidak dapat merasakannya. Selain itu dikarenakan rendahnya motivasi dan minat menjadi kendala lain yang menyebabkan masyarakat Kampung Naga sebagian besar belum dapat mencapai pendidikan ke jenjang yang lebih tinggi.

2. Peran pendidikan disini memang sangat membantu menambah wawasan dari masyarakat sendiri walaupun begitu tak serta merta pendidikan yang berasal dari 
luar ini menjadikan pola pikir masyarakat Kampung Naga berubah dikarenakan mereka memiliki filosofi yang mana wawasan boleh global akan tetapi perilaku tetap lokal.

\section{SARAN}

Berdasarkan kesimpulan di atas, adapun saran yang dapat diberikan kepada masyarakat adat Kampung Naga bahwa:

1. Peningkatan motivasi dan minat dari dalam keluarga dalam pendidikan khususnya pendidikan formal perlu ditingkatkan mengingat banyaknya beasiswa yang ditawarkan sehingga anak dapat memperoleh pendidikan setinggitingginya.

Peran Pemerintah Daerah Kabupaten Tasikmalaya untuk mendorong masyarakat adat Kampung Naga untuk menempuh pendidikan formal perlu ditingkatkan.

\section{DAFTAR PUSTAKA}

Adi W Gunawan. (2008). The Secret of Mindset. Jakarta: Gramedia

Bimo, Walgito. (1999). Psikologi Sosial. Yogyakarta: Penerbit Andi

Damanik, Suri Handayani. (2010). Hubungan Persepsi Tentang Keterampilan Guru Mengajar dengan Motivasi Belajar Siswa Kelas Akselerasi Untuk Mata Pelajaran Sosiologi di SMA Swasta Al-Azhar Medan.

Koontz, Harold. 1990. Management, Jilid II. Erlangga: Jakarta.

Miler, Mattew B dan A. Michael Huberman. (2007). Analisis Data Kualitatif, Buku sumber tentang metode-metode baru. Jakarta: Universitas Indonesia Press

Moleong, Lexi J. (2011). Metode Penelitian Kualitatif. Bandung: Remaja Rosda.

Putra, Ardyansah Jani. (2012). Pengaruh Minat Dan Motivasi Siswa Dalam Kegiatan Ekstrakurikuler Seni Musik Terhadap Prestasi Belajar Seni Budaya Di Smp Negeri 1 Wates. Yogyakarta: Diss. Universitas Negeri Yogyakarta.

Undang - Undang Nomor 20 Tahun 2003 tentang Sistem Pendidikan Nasional. Winkel, W.S. (1996). Psikologi Pengajaran. Jakarta: PT. Raja Grafindo Persada. Witherington. (1985) . Psikologi Pendidikan. Jakarta: Aksara Baru 